\title{
Geochemical Analyses of Domestic Groundwater Sources in Okeagbe-Akoko, Southwestern Nigeria.
}

\author{
Muslim B. Aminu ${ }^{1}$, Opemipo, O. Ajayi ${ }^{1}$, Olusola G. Adelabu ${ }^{1}$ \\ ${ }^{1}$ Department of Earth Sciences, Adekunle Ajasin University, Akungba-Akoko, Nigeria
}

\begin{abstract}
Geochemical analyses of domestic groundwater sources within Okeagbe-Akoko, South-western Nigeria have been conducted. A total of twenty (20) water samples, sourced from hand-dug wells, deep wells and streams, were analyzed for their physico-chemical characteristics, with the aim of determining their suitability for local domestic consumption. The physico-chemical analyses involved the determination of Electrical Conductivity (EC), Acidity ( $p H)$, Total Dissolved Solids (TDS) and the determination of the concentration of a heavy metals suite consisting of Zinc (Zn), Nickel (Ni), Cadmium (Cd), Copper (Cu), Lead $(\mathrm{Pb})$, and Chromium (Cr), using the Atomic Absorption Spectrometry (AAS). Result ranges obtained for the physical parameters were $\mathrm{pH}$ : 5.82 to 7.08 , total dissolved solids: 43 to $492 \mathrm{mg} / \mathrm{l}$, and electrical conductivity: 71.681 to $820.164 \mu \mathrm{s} / \mathrm{cm}$. The heavy metal concentrations for $\mathrm{Cu}$ and $\mathrm{Zn}$ ranged from 0.001 to $0.014 \mathrm{mg} / \mathrm{l}$ and 0.001 to $0.030 \mathrm{mg} / \mathrm{l}$ respectively. $\mathrm{Ni}, \mathrm{Cd}, \mathrm{Pb}$ and $\mathrm{Cr}$ were not detected in any of the water samples. All determined physico-chemical parameters were well below the current World Health Organization (WHO) acceptable limits for safe water sources. This indicates that the domestic water sources in the area are relatively contaminant free and safe for domestic use. The $\mathrm{Cu}^{2+}$ concentration distribution pattern however, provides insight into the likely nature of heavy metal contaminant migration path in the event of an impact.
\end{abstract}

Keywords :Domestic water sources, physico-chemical properties, water quality, Atomic Absorption Spectrometry (AAS), heavy metal concentration.

\section{INTRODUCTION}

Studies have shown that the management of urban and rural waste has been a serious problem in Nigeria [1,2]. The concept of promoting better health which dates back to 1860 , placed emphasis on safe water supply, proper management of feces and refuse disposal. The major concerns include the increasing volume of refuse which is generated as a result of urbanization and population growth, and pollutants derived when biological, chemical and physical processes such as the biological decay of organic materials, and the dissolution and leaching of organic and inorganic materials into groundwater sources. During the process of decomposition certain acids (particularly carbonic acid) are formed and these act to dissolve soil minerals and other residues [3]. When domestic refuse (synthetic household products, metallic scraps, pieces of clothes, etc.) is dumped, it decays, and the organic matter as well as animal and other waste products yield micro-organisms such as fungi and bacteria respectively, which pollute the surrounding water.

In Nigeria, there is an abundance of surface and groundwater resources, particularly in the SouthWestern region which lies entirely within the tropical rainforest zone [4]. However, the quality of groundwater depends upon several factors such as lithology and conditions prevailing within formations, the amount of water available in the aquifer and its rate of circulation. Apart from these factors, the activities of micro-organisms, temperature and pressure are also responsible for the chemical characteristic of groundwater. Thus, groundwater is not entirely pure water because it usually contains dissolved mineral ions [5].

Poor water quality is a significant problem in many parts of the world as the World Health Organization (WHO) estimates that more than $20 \%$ of the world population have no safe drinkable water and more than $40 \%$ lack adequate sanitation [6]. In this paper, we present the results of our investigation of possible contamination of communal water sources in Okeagbe-Akoko, southwestern Nigeria. The key objective of the study was to determine the suitability of domestic water sources in the area for human consumption.

\section{Study Area}

Okeagbe-Akoko is the headquarters of Akoko Northwest Local Government Authority of Ondo State. It falls within the basement complex of southwestern Nigeria. The area lies between longitudes $5^{\circ} 43^{\prime}$ and $5^{\circ} 49^{\prime}$ $\mathrm{E}$ and latitudes $7^{0} 36^{\prime}$ and $7^{0} 40^{\prime} \mathrm{N}$ (Figure. 1). The area is characterized by a relatively rugged and undulating topography with outcropping rocks attaining elevation ranges between 600 and 1500 feet above sea level. The area is accessible by roads and footpaths and it occupies an aerial extent in excess of $56 \mathrm{~km}^{2}$. The mean annual rainfall is $150 \mathrm{~cm}$, the mean annual relative humidity is above $80 \%$ and the mean annual temperature is about $22^{\circ} \mathrm{C}$. Vegetation reflects the deciduous Guinea Savannah with light forests, shrubs and scattered cultivation. 
The area is well drained by numerous perennial and seasonal streams and streamlets. The rock suite within the area consists mainly of gneissic rocks (grey gneiss, granite gneiss, biotitic gneiss) and charnokites. The area is believed to have undergone at least two episodes of metamorphism and subsequent brittle deformation $[7,8]$. This has given rise to intense folding and fracturing of the rock suites. The predominant geologic strike is NWSE. Trend direction for fold hinges is bipolar with a predominant WNW-ESE trend and a minor N-S trend. Fracture orientation on the other hand is strongly unipolar with an essentially N-S trend [9]. Aquifer types within such areas are restricted to fracture zones and regions of deep weathering [10].

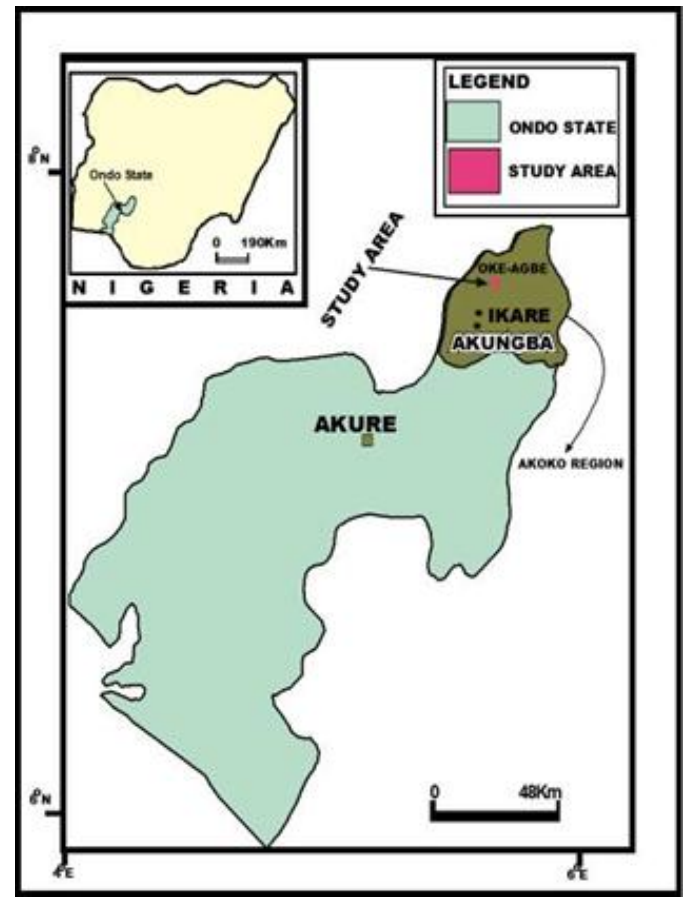

Fig 1: Map of Ondo State Showing the study area Okeagbe-Akoko.

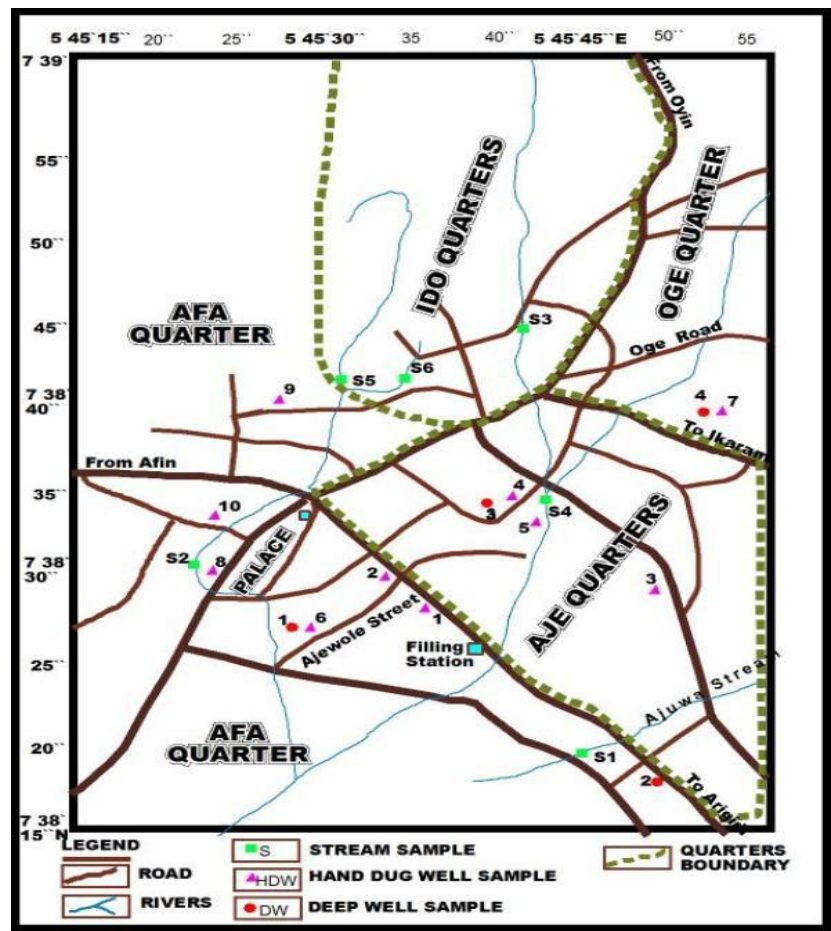

Fig. 2: Street map of Okeagbe-Akoko. Sample collection points are shown as streams (green squares), handdug well (purple triangles) and deep wells (red spheres). 


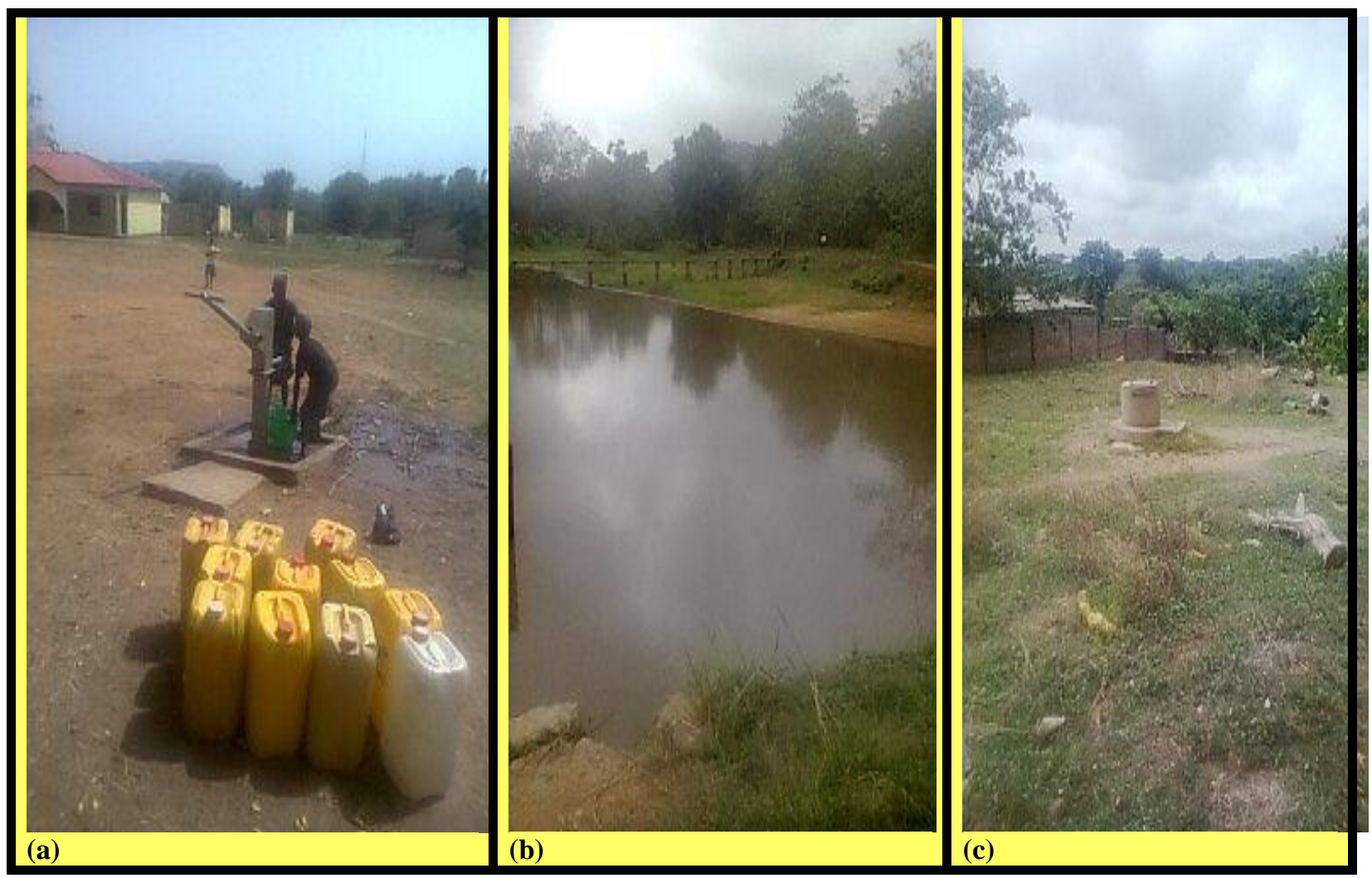

Fig. 3: Most of domestic water sources in and around Okeagbe-Akoko are exposed to the atmosphere and therefore susceptible to surface contaminants from indiscriminate waste disposal and improper fecal discharge. (a) Deep well, (b) Stream and (c) Hand-dug well.

The WHO has developed a series of normative guidelines for assessment of health risk and hazards through water (See Table 1). These principal guidelines are intended to assist countries in establishing effective national or regional strategies and standards. The physical parameters such as $\mathrm{pH}, \mathrm{EC}$, TDS with other heavy metal concentrations should be within the WHO acceptable standards. Therefore, the results of the current analyses are compared with WHO 2012 set standards in order to evaluate the groundwater quality and suitability for domestic use in the study area.

\section{Discussion}

Table 2 gives the detailed results of physico-chemical analyses conducted on the water samples while Table 3 gives the ranges and spread of $\mathrm{pH}$, conductivity and total dissolved solids according to water sources type.

$\mathrm{pH}$ values obtained range from 5.84 to 7.08 . Stream samples show the highest $\mathrm{pH}$ variation of all three sources, ranging from 5.84 to 7.04 (a spread of 1.2) while deep wells have the narrowest range of 6.47 to 7.08 (a spread of 0.61). This trend is expected and can be attributed to the exposure of stream sources to the free surface. This makes them more susceptible to contaminant influence and hence broadens the range of acidity. Nonetheless, all $\mathrm{pH}$ values obtained were neutral to acidic. This indicates the presence of free carbon IV and that the inorganic carbon exists almost entirely as bicarbonate ion [11]. $\mathrm{pH}$ values for deep wells are generally within the WHO standards for safe drinking water. However, half of stream samples tested and half of the samples from HDW gave $\mathrm{pH}$ values not within the WHO range of $6.5-8.5$. This could pose a health risk to inhabitants within the area as these sources make up the bulk of domestic water sources within the area.

The total dissolved solids (TDS) ranges from 43 to $492 \mathrm{mg} / \mathrm{l}$ and conductivity of water samples taken ranges between 71.681-820.164 $\mu \mathrm{Scm}^{-1}$. TDS concentration and conductivity are highest for HDW with values ranging from 170 to $492 \mathrm{mg} / \mathrm{l}$ and 220 to $820.2 \mu \mathrm{S} / \mathrm{cm}$ respectively and averages of $303.4 \mathrm{mg} / 1$ and 492.4 $\mu \mathrm{S} / \mathrm{cm}$. The lowest values are for stream samples with values in the ranges of 43 to $372 \mathrm{mg} / \mathrm{l}$ and 71.7 to 560.1 $\mu \mathrm{S} / \mathrm{cm}$ and averages of $214.5 \mathrm{mg} / 1$ and $313.1 \mu \mathrm{S} / \mathrm{cm}$ for TDS and conductivity respectively. There is an obvious correlation between TDS and conductivity. The conductivity of a solution is a function of both the total amount 
of salts in solution and salt ionization. We attribute higher TDS and conductivity of HDW relative to samples from other sources to the fact that HDW abstract water principally from the weathered rock column (overburden). This usually contains greater amounts of salts which are released during weathering of the parent rock. On the other hand, deep wells in basement terrains generally abstract water from within the relatively unweathered fractured basement. Weathering in this column is minimal (with the exception of fractures) and therefore, water in this column contains lower amounts of released salts. We attribute the lower TDS and conductivity values obtained from stream samples to the effect of heavy leaching of the surficial material on the stream bed. The continuous vigorous flow of water through the stream channel would engender the removal of the salts released during weathering from the channel.

All samples tested, irrespective of source, have TDS and conductivity values which fall within the WHO standards of $500 \mathrm{mg} / \mathrm{l}$ and $1000 \mu \mathrm{S} / \mathrm{cm}$ respectively. It is therefore expected that the salt concentrations and conductivity levels of water sources within Okeagbe-Akoko pose no health risks to local who utilize them for domestic consumption.

Table 1: Summary of Physical and Chemical Characteristics and WHO (2012) standards for drinking water

\begin{tabular}{|l|l|l|l|}
\hline Parameter & Unit & $\begin{array}{l}\text { Maximum } \\
\text { Permitted } \\
\text { Levels }\end{array}$ & Indicated Health Impact \\
\hline Copper $(\mathrm{Cu})$ & $\mathrm{mg} / \mathrm{l}$ & 2 & Gastro-intestinal disorder \\
\hline Lead $(\mathrm{Pb})$ & $\mathrm{mg} / \mathrm{l}$ & 0.01 & $\begin{array}{l}\text { Cancer, interference with Vitamin D metabolism, affects mental } \\
\text { development in infants, toxic to the central and peripheral nervous } \\
\text { systems. }\end{array}$ \\
\hline Cadmium $(\mathrm{Cd})$ & $\mathrm{mg} / \mathrm{l}$ & 0.003 & Toxic to the kidney \\
\hline Chromium $(\mathrm{Cr})$ & $\mathrm{mg} / \mathrm{l}$ & 0.05 & Cancer \\
\hline Nickel $(\mathrm{Ni})$ & $\mathrm{mg} / \mathrm{l}$ & 0.02 & Possibly carcinogenic \\
\hline Zinc $(\mathrm{Zn})$ & $\mathrm{mg} / \mathrm{l}$ & 3 & Nausea, cramps, diarrhea, and associated headaches. \\
\hline $\mathrm{pH}$ & - & $6.5-8.5$ & Rusting, cancer \\
\hline Conductivity & $\mu \mathrm{S} / \mathrm{cm}$ & 1000 & Anemia, liver, kidney or spleen damage, changes in blood \\
\hline $\begin{array}{l}\text { Total Dissolved } \\
\text { Solids }\end{array}$ & $\mathrm{mg} / \mathrm{l}$ & 500 & Stomach discomfort \\
\hline
\end{tabular}

Table 2: Results of $\mathrm{pH}$, Electrical conductivity (EC), Total dissolved solids (TDS) and heavy metal concentrations for water samples taken from Okeagbe-Akoko. $\mathrm{Ni}, \mathrm{Cd}, \mathrm{Pb}$ and $\mathrm{Cr}$ were not detected in any of the samples. WHO standard limits for $\mathrm{Zn}$ and $\mathrm{Cu}$ are 3 and $2 \mathrm{mg} / \mathrm{l}$ respectively. (HDW = Hand Dug Well. DW = Deep Well. $\mathrm{S}=$ Stream). pH values (largely for stream and hand dug well samples) not within the WHO limits are highlighted bold.

\begin{tabular}{|c|c|c|c|c|c|c|c|c|}
\hline \multirow{2}{*}{$\begin{array}{l}\text { Sample } \\
\text { Number }\end{array}$} & \multirow[t]{2}{*}{ Sample Id } & \multicolumn{2}{|c|}{ Location coordinates } & \multirow[t]{2}{*}{ pH } & \multirow{2}{*}{$\begin{array}{l}\text { Conductivity } \\
(\mu \mathrm{S} / \mathrm{cm})\end{array}$} & \multirow{2}{*}{\begin{tabular}{|l|} 
Total \\
Dissolved \\
Solids (mg/l)
\end{tabular}} & \multirow{2}{*}{$\begin{array}{l}\mathbf{Z n}^{2+} \\
(\mathbf{m g} / \mathbf{l})\end{array}$} & \multirow{2}{*}{$\begin{array}{l}\mathrm{Cu}^{2+} \\
(\mathrm{mg} / \mathrm{l})\end{array}$} \\
\hline & & Latitude & Longitude & & & & & \\
\hline 1 & S1 DW & $\mathrm{N} 7^{0} 38.4334^{\prime}$ & $\mathrm{E}^{0} 45.5194^{\prime}$ & 6.95 & 530.1 & 318 & - & 0.001 \\
\hline 2 & S2 HDW & $\mathrm{N}^{0} 38.5324^{\prime}$ & $\mathrm{E}^{0} 45.6733^{\prime}$ & 6.86 & 616.8 & 370 & 0.001 & 0.003 \\
\hline 3 & S3 HDW & $\mathrm{N} 7^{0} 38.4463^{\prime}$ & $\mathrm{E}^{0} 45.6081^{\prime}$ & 6.40 & 820.2 & 492 & - & 0.006 \\
\hline 4 & S4 S & $\mathrm{N}^{0} 38.3306^{\prime}$ & $\mathrm{E}^{0} 46.0299^{\prime}$ & 6.20 & 71.7 & 43 & - & 0.006 \\
\hline 5 & S5 S & $\mathrm{N} 7^{0} 38.0473^{\prime}$ & $\mathrm{E}^{0} 45.8948^{\prime}$ & 6.99 & 100.0 & 60 & 0.030 & 0.006 \\
\hline 6 & S6 DW & $\mathrm{N} 7^{0} 38.2746^{\prime}$ & $\mathrm{E}^{0} 45.7872^{\prime}$ & 7.08 & 366.7 & 220 & - & 0.007 \\
\hline 7 & S7 DW & $\mathrm{N}^{0} 38.6116^{\prime}$ & $\mathrm{E}^{0} 45.6697^{\prime}$ & 6.47 & 570.1 & 342 & - & 0.011 \\
\hline 8 & S8 HDW & $\mathrm{N} 7^{0} 38.5998^{\prime}$ & $\mathrm{E}^{0} 45.7095^{\prime}$ & 6.00 & 641.8 & 385 & - & 0.009 \\
\hline 9 & S9 HDW & $\mathrm{N} 7^{0} 38.5185^{\prime}$ & $\mathrm{E}^{0} 45.7948^{\prime}$ & 6.59 & 620.1 & 372 & - & 0.008 \\
\hline 10 & S10 HDW & $\mathrm{N} 7^{0} 38.5460^{\prime}$ & $\mathrm{E}^{\circ} 45.7439^{\prime}$ & 6.52 & 440.1 & 264 & - & 0.009 \\
\hline 11 & S11 S & $\mathrm{N} 7^{0} 38.8384^{\prime}$ & $\mathrm{E}^{0} 45.5202^{\prime}$ & 6.87 & 458.4 & 275 & - & 0.010 \\
\hline 12 & S12 S & $\mathrm{N}^{0} 39.1291^{\prime}$ & $\mathrm{E}^{0} 45.7517^{\prime}$ & 5.84 & 353.4 & 372 & - & 0.011 \\
\hline 13 & S13 DW & $\mathrm{N}^{0} 38.9932^{\prime}$ & $\mathrm{E}^{0} 45.7984^{\prime}$ & 6.87 & 363.4 & 218 & - & 0.012 \\
\hline 14 & S14 HDW & $\mathrm{N} 7^{0} 38.4047^{\prime}$ & $\mathrm{E}^{0} 45.4923^{\prime}$ & 6.20 & 510.1 & 306 & - & 0.012 \\
\hline 15 & S15 HDW & $\mathrm{N}^{0} 38.3086^{\prime}$ & $\mathrm{E}^{0} 45.3958^{\prime}$ & 6.42 & 338.4 & 203 & - & 0.012 \\
\hline 16 & S16 HDW & $\mathrm{N}^{0} 38.4259^{\prime}$ & $\mathrm{E}^{0} 45.3196^{\prime}$ & 5.98 & 433.4 & 260 & - & 0.013 \\
\hline 17 & S17 HDW & $\mathrm{N}^{0} 38.3793^{\prime}$ & $\mathrm{E}^{0} 45.2907^{\prime}$ & 7.02 & 283.4 & 170 & - & 0.013 \\
\hline 18 & S18 HDW & $\mathrm{N} 7^{0} 38.2779^{\prime}$ & $\mathrm{E}^{0} 45.5644^{\prime}$ & 6.82 & 220.0 & 212 & - & 0.014 \\
\hline 19 & S19 S & $\mathrm{N}^{0} 38.4161^{\prime}$ & $\mathrm{E}^{0} 45.7252^{\prime}$ & 6.39 & 335.1 & 201 & - & 0.014 \\
\hline 20 & S20 S & $\mathrm{N}^{0} 38.6771^{\prime}$ & $\mathrm{E}^{0} 45.8041^{\prime}$ & 7.04 & 560.1 & 336 & - & 0.013 \\
\hline
\end{tabular}


Geochemical Analyses of Domestic Groundwater Sources in Okeagbe-Akoko, Southwestern Nigeria.

Table 3: Summary of physical test results; range from minimum to maximum, size of the spread and mean values for $\mathrm{pH}, \mathrm{EC}$ and TDS.

\begin{tabular}{|l|l|l|l|l|l|l|l|l|l|}
\hline \multirow{2}{*}{$\begin{array}{l}\text { Sample } \\
\text { source }\end{array}$} & $\mathrm{pH}$ & \multicolumn{3}{|l|}{ Conductivity $(\mu \mathrm{S} / \mathrm{cm})$} & \multicolumn{2}{|c|}{ Total dissolved Solids $(\mathrm{mg} / \mathrm{l})$} \\
\cline { 2 - 10 } & Range & Spread & Mean & Range & Spread & Mean & Range & Spread & Mean \\
\hline DW & $6.47-7.08$ & 0.61 & 6.84 & $363.4-570.1$ & 206.7 & 457.6 & $218-342$ & 134 & 274.5 \\
\hline HDW & $\mathbf{5 . 9 8}-7.02$ & 1.04 & 6.48 & $220-820.2$ & 600.2 & 492.4 & $170-492$ & 322 & 303.4 \\
\hline S & $\mathbf{5 . 8 4}-7.04$ & 1.20 & 6.55 & $71.7-560.1$ & 488.4 & 313.1 & $43-372$ & 329 & 214.5 \\
\hline
\end{tabular}

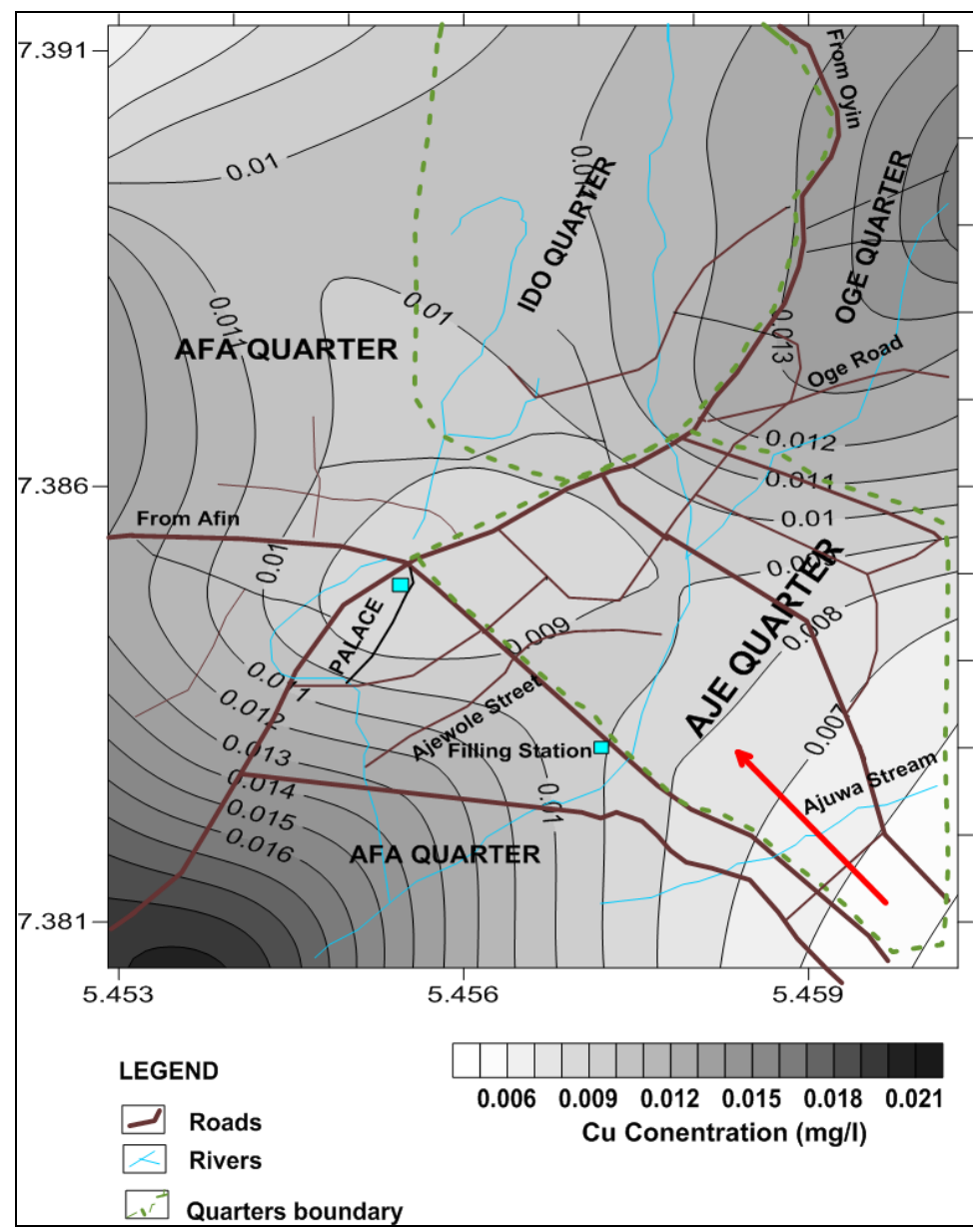

Fig. 4: Contour map of $\mathrm{Cu}$ concentrations in the study area. Low $\mathrm{Cu}$ Concentration trend (red arrow) strongly coincides with the principal WNW-ESE geologic strike direction within the study area suggesting that heavy metal ion migration within the area is strongly influenced by geologic strike.

$\mathrm{Pb}, \mathrm{Cr}, \mathrm{Ni}$ and $\mathrm{Cd}$ were undetected in all samples. $\mathrm{Zn}$ was detected in very low concentrations of $0.001 \mathrm{mg} / \mathrm{l}$ and $0.03 \mathrm{mg} / \mathrm{l}$ in two samples, a HDW and a stream sample. These values are well below the maximum limit of 3 $\mathrm{mg} / \mathrm{l}$ set by WHO. We conclude that the Zn concentration in domestic water sources in the study area present no health risk to the locals who utilize it. $\mathrm{Cu}$ was detected, though also in relatively low concentrations in all samples. Concentration ranged from 0.001 to $0.014 \mathrm{mg} / \mathrm{l}$. This also is well below the WHO standard limit of 2 $\mathrm{mg} / \mathrm{l}$. We again conclude that $\mathrm{Cu}$ concentrations in domestic water sources in the study areas would pose no health risk to the locals. However, the distribution map (figure 4) of $\mathrm{Cu}$ concentration shows a strong congruence between preferential $\mathrm{Cu}$ concentration and the regional geologic strike of the suite of rocks within the area. Strikes measured on outcropping rocks in the area indicate an approximately WNW - ESE trend. This strongly coincides with a low $\mathrm{Cu}$ concentration path seen straddling the area in a nearly NW - SE. This straddle appears as a low concentration barrier which separates higher concentration regions to the NE and SW of the area. This would indicate that $\mathrm{Cu}$ concentrations and possibly migration trends in the area is controlled by geologic strike. In the event therefore, of heavy ion contamination in the area, it can be expected that plume migration will be along the predominant WNW - ESE geologic strike direction. This insight could prove valuable for contaminant containment and remediation future. 


\section{CONCLUSION}

Twenty water samples taken from various locations in Okeagbe-Akoko and representing different sources of domestic water utilized by the inhabitants of the area have been subjected to analyses to determine the physico-chemical characteristics and the suitability of the water sources employ for domestic use vis. a vis. the WHO standard. TDS and conductivity values obtained and the heavy metal concentrations of $\mathrm{Zn}$ and $\mathrm{Cu}$ detected are well below the current WHO acceptable limit for water safe for domestic consumption. However, $\mathrm{pH}$ values obtained for half of each of the stream and HDW samples fall outside the WHO acceptable limit for safe drinking water. These sources make up about $80 \%$ of available water sources in the area and could indicate potential health risk for locals who utilize them. On the whole, we conclude that water sources within OkeagbeAkoko Township are relativity safe for consumption and have not been adversely impacted by contamination sources such as inadequate waste disposal, and industrial and agro-Allied chemical release into the environment.

The $\mathrm{Cu}$ concentration distribution gives us insight into possible immigration pathways for heavy metal ions contaminants in the event of an impact. As the town grows and industrializes, such a scenario becomes increasingly plausible. It therefore is imperative that further development and waste management plans take into cognizance this indicated migration trend.

\section{References}

[1] S. Adejobi, and R.O. Olorunnimbe, Challenges of Waste Management and Climate Change in Nigeria: Lagos State Metropolis Experience, African Journal of Scientific Research. 7(1), 2012, (http://www.journalsbank.com/ajsr 7 3.pdf)

[2] A. A. Fakere, G. Fadairo, and O. Oriye, Domestic Waste Management and Urban Residential Environment: Focus on Akure, Nigeria. International Journal of Engineering and Technology, 2(5), 2012, 878 - 887.

[3] A. A. Agboola, and C. R. Obatolu, Problems and Prospects of Maintaining Continuous Arable Production in the Humid Tropics through Soil Organic Matter Management, International symposium on Role of Biology in Resolving Food Crisis in Africa, Yamoussoukro, Cote d'Ivoire, July 1989.

[4] T. D. T. Oyedotun, and O. Obatoyinbo, Hydro-geochemical Evaluation of Groundwater Quality in Akoko North West local government area of Ondo State, Nigeria, Ambi-Agua, Taubaté. 7, 2012, 67-80.

[5] C. O. Okagbue, Hydrology and Chemical Characteristics of Surface and Groundwater Resources of the Okigwi area and environs, Imo State, Nigeria. In: Ofoegbu, C.O. (Ed.). Groundwater and mineral resources of Nigeria. (Braunschweig: Vieweg and Sohn, Germany, 1988) 3 - 16.

[6] J. W. Oastridge, and R. Trents, Why is fresh water an issue for business? Background Paper. Can $176-$ oa.tr. (United Nations CDS, 1999) P. 9.

[7] M. A. Rahaman, Review of the Basement Complex Geology of Southwestern Nigeria: In Kogbe, C. A (Eds). (Elizabethan Publishing Company, Lagos, 1976), 41 - 58.

[8] M. A. Rahaman, Recent advances in the study of the basement complex of Nigeria. In Precambrian Geology of Nigeria, (Geological Survey of Nigeria, Kaduna, 1988) $11-43$.

[9] M. B. Aminu, A. O. Oluwajana, and P. S. Ogunleye, Structural Analyses of Gneissic Rocks in Akungba-Akoko, Southwestern Nigeria. (Personal communication).

[10] M. O. Olorunfemi, and M. A. Olorunniwo, Geoelectric Parameters and aquifer characteristics of some parts of Southern Nigeria. Geol. Appl. E. Idrogeol. 20, 1985, $99-109$.

[11] R. A. Freeze, and J. A. Cherry, Groundwater Hydrology (Prentice Hall, Upper Saddle River, New Jersey. 1979) 